\title{
A Justiça Eleitoral brasileira: modelo de governança eleitoral
}

\section{Alvaro Augusto de Borba Barreto}

\section{Resumo}

Este artigo analisa o modelo institucional da Justiça Eleitoral brasileira a partir das contribuições da concepção de governança eleitoral, de modo a construir uma compreensão mais ampla e sistemática a respeito dele. É construído por meio da revisão da literatura das áreas de Ciência Política e de Direito Eleitoral e da composição dessas contribuições com os novos parâmetros interpretativos trazidos por essa abordagem. Desse modo, apresenta os elementos que constituem a noção de governança eleitoral, caracteriza os diferentes modelos implantados historicamente e insere nesse campo aquele correspondente ao adotado pelo Brasil a partir de 1932. Os resultados indicam que a Justiça Eleitoral corresponde a um modelo de governança eleitoral que possui prerrogativas distintas em comparação aos equivalentes internacionais, construído a partir de uma decisão política consciente e que vem sendo continuamente reafirmada, razão pela qual o papel, os poderes e as funções exercidas por esse organismo eleitoral continuam essencialmente os mesmos desde sua adoção.

Palavras-chave: Justiça Eleitoral; governança eleitoral; revisão de poderes; poder normativo; consultas.

\begin{abstract}
The article analyzes the institutional model of the Brazilian Electoral Justice from the contributions of electoral governance design in order to build a more comprehensive and systematic understanding about it. It is built by reviewing the literature in the areas of Political Science and Election Law and the composition of these contributions with the new interpretive parameters brought by that approach. Thus, presents the elements that constitute the notion of electoral governance, characterizes the different models implemented historically and inserts in this field the one corresponding to the one adopted by Brazil since 1932. The results indicate that the Electoral Justice corresponds to an electoral governance model that has different prerogatives compared with international equivalents, constructed from a conscious political decision and
\end{abstract}

\section{Sobre o autor}

Doutor em História, especialista em Ciência Política pela Universidade Federal de Pelotas (UFPel), docente de Ciência Política no Programa de Pós-Graduação nessa instituição. E-mail: albarret.sul@terra.com.br 
that has been continuously reaffirmed, the reason why the role, powers and functions exercised by the electoral management board remain essentially the same since its adoption.

Keywords: Electoral Justice; electoral governance; review of powers; normative power; consultations.

Artigo recebido em 29 de setembro de 20I4; aceito para publicação em 2 de junho de 2015.

\section{Introdução}

Este artigo analisa as características da Justiça Eleitoral brasileira a partir da concepção de governança eleitoral. Além de apresentar as concepções em torno desse tema e o modo como ele vem sendo trabalhado na literatura, compara a Justiça Eleitoral brasileira aos modelos de governança eleitoral que a antecederam e se dedica a discutir as peculiaridades que a constituem desde sua criação em 1932.

Está calcado em revisões bibliográficas, tendo como fontes textos dos campos da Ciência Política e do Direito Eleitoral, e estrutura-se em três seções: a primeira está centrada no conceito de governança eleitoral; a segunda abrange os padrões dessa governança adotados no país antes da implantação de 1932; e a terceira discute o arranjo institucional que constitui a Justiça Eleitoral.

\section{Governança eleitoral}

Em uma concepção minimalista ou procedimental de democracia, as eleições se tornam o método por excelência para a seleção de autoridades políticas, fonte da legitimidade imprescindível para o exercício do poder político (Schumpeter, 1984; Bobbio, 1997). No entanto, regimes não democráticos utilizam-se ou podem utilizar-se das eleições; logo, elas são condição necessária, mas não suficiente para que um sistema seja considerado democrático. Para atingir tal classificação, é preciso que, nessas eleições: o direito de voto seja amplo e as vontades possam ser livremente formadas e manifestadas; as regras que disciplinam a competição garantam a incerteza e haja efetiva possibilidade de mudança, isso é, que o resultado não esteja antecipadamente predeterminado, e sim sujeito à disputa entre os concorrentes (Przeworski, 1984); o jogo tenha continuidade e seja 
periódico, assim os vencedores cumprem mandatos limitados no tempo. Sinteticamente: as eleições devem ser justas, livres, frequentes e competitivas ${ }^{1}$, como ensina Dahl (2001).

$\mathrm{Na}$ literatura mais recente da Ciência Política, o conceito que busca abranger esses requisitos é o de "governança eleitoral”, compreendido como "um grande número de atividades que cria e mantém o vasto arcabouço institucional no qual se realizam o voto e a competição política" (Mozaffar e Schedler, 2002, 7, tradução minha).

Contudo, esse enunciado é "neutro" e apenas descreve os mecanismos que propiciam a realização de um processo eleitoral, seja ele qual for. Desse modo, no caso dos sistemas efetivamente (e não apenas nominalmente) democráticos, a legitimidade da origem e da fundamentação dos mandatos eletivos implica estabelecer

padrões de confiabilidade, imparcialidade política, correção e eficácia administrativa da authority da administração e condução do processo eleitoral e dos procedimentos correlatos de fiscalização, votação, apuração e proclamação dos resultados (Pelella, 2012, 134).

\section{Ou, como expõe Henríquez $(2007,1153)$ :}

proteção autêntica ou tutela eficaz do direito de eleger ou de ser eleito para desempenhar um cargo público, mediante um conjunto de garantias aos participantes (partidos políticos e, no caso, cidadãos e candidatos) com vistas a impedir que possa ser violada a vontade popular, contribuindo para assegurar a legalidade, certeza, objetividade, imparcialidade, autenticidade, transparência e justiça dos atos e dos procedimentos eleitorais (tradução minha).

Mozaffar e Schedler $(2002,11)$ ponderam que uma governança eleitoral adequada às eleições limpas e à salvaguarda da "verdade das urnas" é importante para a legitimidade dos eleitos, mas também para a estabilidade do regime, a aceitação dos resultados pelos diferentes competidores e a pacificação do processo político. Eles afirmam, seguindo os termos da assertiva de Przeworski (1984), que

1. Para Sartori (1982), a expressão indica que as regras devem garantir um patamar equitativo de condições para os concorrentes, embora eventualmente a disputa não se apresente competitiva, ou seja, há um desequilíbrio de performance entre eles. 
"a tarefa central da governança eleitoral é institucionalizar a incerteza democrática" (tradução minha), ou seja, garantir a existência de regras claras, as quais são aplicadas com isenção e transparência, e que por isso subsidiam a livre disputa e sustentam a credibilidade do processo eleitoral como um todo.

Ela compreende três diferentes níveis: a) formulação das regras (rule making); b) aplicação das regras (rule application); c) resolução dos conflitos (rule adjudication). Embora discerníveis no plano analítico, é o conjunto que promove a qualificação da governança eleitoral, pois riscos e ameaças perpassam cada um desses níveis (Mozaffar e Schedler, 2002, 7).

O "rule making" seria a escolha e a definição das regras básicas do jogo eleitoral. Nesse nível [...] são determinados, por exemplo, a fórmula eleitoral, os distritos eleitorais, a magnitude das eleições, as datas em que serão realizadas e outras questões legais que permitam aos concorrentes a segurança de como o jogo será jogado. Aqui também são definidas algumas regras que pouca atenção recebem da literatura política, como as regras da (in)elegibilidade e da organização dos órgãos responsáveis pela administração das eleições (Marchetti, 2008, 867).

Ele é promovido antes da realização do processo eleitoral propriamente dito, pois estrutura a disputa ${ }^{2}$. Nesse sentido, a existência de um consenso em torno da razoabilidade das regras é condição necessária para a disposição dos jogadores para participar do pleito e aceitar o resultado que ele apresentar (Mozaffar e Schedler, 2002, 10).

O rule application envolve a "implementação e o gerenciamento do jogo eleitoral" (Marchetti, 2008, 867) e engloba procedimentos que: antecedem a votação, como o credenciamento dos eleitores e dos próprios competidores; perpassam a coleta dos votos; e se encerram com a contagem desses sufrágios, a publicação dos resultados e a diplomação dos eleitos. Três são os desafios: obter eficiência administrativa para empreender a difícil e complexa tarefa de promover

2. Mozaffar e Schedler $(2002,7)$ falam no "metajogo", anterior ao rule making, que é a regra que define quem tem a autoridade para definir as regras da governança eleitoral. 
um pleito; apresentar neutralidade política; e promover prestação de contas das decisões (Mozaffar e Schedler, 2002, 8-10).

O rule adjudication, por sua vez, envolve a solução dos litígios entre os competidores e ocorre antes, durante e depois da votação, visto que eles podem surgir em qualquer dessas etapas. Oliveira (2009, 23) alerta que o controle do procedimento eleitoral não se restringe ao contencioso, e sim o abrange, pois muitas atividades implicam fiscalizar a aplicação das regras em sua dimensão administrativa, sem que seja necessária a existência de litígio entre os competidores.

Marchetti (2008) explica que os três níveis de governança eleitoral geralmente não estão concentrados em um único órgão. As regras são quase sempre definidas no texto constitucional e em legislação infraconstitucional, enquanto a aplicação das regras e a adjudicação são de responsabilidade do Electoral Management Board (EMB) ou Organismo Eleitoral (OE). Quando as duas últimas tarefas são de responsabilidade de instituições diferentes, a que cuida do contencioso costuma ser identificada como Electoral Dispute Resolution Bodies (EDRB) (Tarouco, 2014).

A literatura que versa sobre o tema desenvolveu critérios de classificação dos OE. Marchetti (2008) sistematiza-os em: 1) posição institucional, que se refere ao estatuto jurídico e ao posicionamento dele em relação às outras organizações do Estado; 2) vínculo institucional, que abrange as origens e os requisitos básicos exigidos para alguém pertencer ao $\mathrm{OE}$; 3 ) método utilizado para a seleção e indicação de seus membros.

No primeiro critério, a distinção tem por base a existência ou não de ligação do OE com o Executivo, e as modalidades são: governamental, independente e misto. "Governamental" implica que ele é mais um dos órgãos do poder executivo a quem cabe administrar e controlar a lisura das eleições. No caso da "independente", o OE é totalmente dissociado do governo, subdividindo-se em duas possibilidades: composto por uma única instituição ou duas, que tem sido denominada de "duplamente independente", pois uma é responsável por administrar o processo e a outra por decidir o contencioso eleitoral. A modalidade "misto" surge

quando o modelo de governança eleitoral incluir dois organismos com funções distintas, sendo um deles governamental (com a prerrogativa de monitorar, supervisionar e tomar decisões sobre o processo eleitoral) e o 
outro independente (basicamente, atua na implementação do processo eleitoral, sendo o responsável por sua logística) (Ibidem, 870-1).

Quanto ao vínculo institucional dos membros, a distinção inicial reside no fato de ele ser formado ou não por membros de "carreira", entendidos como aqueles recrutados dentre os servidores vinculados ao Executivo. Os OE compostos pelos que não têm esse vínculo se desdobram em: "partidário", cujos membros têm ligação com os partidos; "especializado", quando a escolha exige a ausência desse tipo de relação, centrando-se nos conhecimentos técnicos em matérias eleitorais ou nas qualificações profissionais dos indicados (Ibidem, 872); e "combinado", quando o OE é formado tanto por membros apresentados pelos partidos quanto por especialistas.

$\mathrm{Na}$ visão de Hartlyn et al. $(2009,32)$, que analisaram a relação entre o modo como se organiza a governança eleitoral e a qualidade das eleições na América Latina, "a existência de um OE que demonstre ser independente dos partidos e profissional contribui claramente para melhorar a probabilidade de os processos eleitorais serem mais justos e livres" (tradução. minha). Ou seja, assim como as regras que disciplinam o processo eleitoral contribuem para legitimá-lo junto à sociedade e influenciam o comportamento responsável dos atores envolvidos na disputa, o OE que aplica essas regras e define o contencioso também cumpre papel importante para que esses objetivos sejam atingidos.

Quanto ao modo como são selecionados os membros, é preciso distinguir duas dimensões: a das instituições autorizadas a fazerem a indicação e a dos requisitos necessários para que um indivíduo possa ser indicado. Buscando abranger as duas dimensões, Molina e Hernández (1998) sugerem três categorias: (1) não partidários de designação não política; (2) não partidários de designação política; (3) partidários. Apesar de sintética, calcada nos vínculos partidários, a proposta se mostra insuficiente, pois não engloba as múltiplas combinações possíveis.

Isso porque, no primeiro polo, as possibilidades são: (1) apenas uma instituição faz a indicação, sendo essa partidária ou não partidária; (2) um conjunto faz a indicação e as autorizadas devem ser exclusivamente partidárias, exclusivamente não partidárias ou combinadas. No que tange à identificação de qual ou quais podem exercer tal direito, as possibilidades giram em torno de: governo, 
partidos ou parlamento, presumíveis se o OE é governamental-carreira ou independente-partidário (correspondentes a "partidárias" da classificação de Molina e Hernández); mas bastante diversificadas no caso dos $\mathrm{OE}$ independente-especializados, pois podem ser propostos por: Judiciário, Ministério Público e órgãos da sociedade civil (todas “não partidárias”, conforme Molina e Hernández). É possível também haver ecletismo: uma instituição tem a prerrogativa exclusiva de indicar uma relação de nomes para o(s) cargo(s), mas é outra quem o(s) escolhe e nomeia, nesse caso sendo preciso saber qual é a combinação dessas instituições e as circunstâncias da indicação e da nomeação ${ }^{3}$.

No segundo polo, como as possibilidades são muitas, as alternativas podem ser resumidas em: (1) qualquer um pode ser indicado, desde que cumpra determinados requisitos definidos por lei; logo, se cabe ao legislativo apresentar um nome, a decisão pode ou deve recair sobre um professor universitário, juiz etc., ou seja, a um membro externo ao corpo que faz a indicação; (2) o nome escolhido necessariamente deve pertencer à instituição que o apresenta, o que Marchetti $(2008,877)$ chama de "regra de interseção", traço importante no modelo brasileiro.

\section{Modelos de governança eleitoral em perspectiva histórica}

O primeiro modelo de $\mathrm{OE}$ adotado concentrava todas as prerrogativas no Executivo, o que ocorria quando as eleições não atuavam, efetivamente, como processo de seleção das elites políticas dotadas de mandato livre, e sim como uma deliberação do governante. No dizer de Sampaio (1972, 120-1), como era o Monarca "quem convocava os 'representantes' do reino, a ele também competia reconhecer a qualidade dos eleitos para os seus corpos consultivos".

Posteriormente, surge o que Lehoucq (2002) chama de modelo clássico de governança eleitoral, aquele no qual a administração das eleições é uma atribuição do governo e cabe ao parlamento o controle do contencioso eleitoral.

A responsabilidade do legislativo para a solução de controvérsias sobre a regularidade dos escrutínios e a certificação dos resultados

3. Um exemplo é o Brasil, no qual o STF formula uma lista de advogados para compor o TSE e o Presidente da República faz a escolha. 
das urnas é denominada "revisão" ou "verificação dos poderes", a qual foi adotada inicialmente na Inglaterra do século XVII, embora outras fontes indiquem a primazia da França no século XVI (Sampaio, 1972, 121-2). Independentemente da origem, o fato é que já "no século XIX, as próprias câmaras legislativas - tanto na América Latina como na Europa - eram as últimas instâncias competentes no reconhecimento dos diplomas e, portanto, decidiam definitivamente sobre a validade das eleições" (Ricci e Zulini, 2013, 91-2).

Tal modelo traz como premissa o princípio de separação de poderes e a independência funcional do parlamento em relação ao Executivo, ou seja, que a definição da regularidade da eleição e da elegibilidade dos membros dos órgãos legislativos cabe a ele próprio (ou à parte dele autorizada para esse fim) (Ribeiro, 1996, 109-10; Oliveira, 2009, 28). Como pondera Henríquez (2007, 1157), nesse modelo prevalece a ideia de que

cada órgão do poder público é independente dos outros, não deve envolver-se nas decisões inerentes à composição dos demais, considerando-se tal medida como uma arma defensiva nas mãos do legislativo frente ao executivo a fim de assegurar sua autonomia e independência (tradução minha).

A "verificação dos poderes" se revelou institucionalmente inadequada para o cumprimento de garantia da autonomia das assembleias representativas (Ribeiro, 1996, 114). Os parlamentos mostravam-se parciais e interessados nos resultados da verificação de poderes, então não tomavam decisões baseadas em princípios normativos, não buscavam o esclarecimento dos fatos relatados e não atentavam para procedimentos como a possibilidade de apresentação de recursos. Ao invés de buscar preservar a lisura do processo eleitoral, os vereditos apresentavam forte tendência a serem discricionários e a beneficiarem as correntes majoritárias (Oliveira, 2009, 29).

Lehoucq $(2002,37)$ enfatiza que a manutenção da responsabilidade de organizar e de qualificar as eleições nas mãos dos partidos produz pleitos manchados pela fraude e que redundam em instabilidade para o sistema político. Isso porque os competidores e a população não acreditam na validade do processo eleitoral, não confiam nem se satisfazem com os resultados e tendem a buscar 
soluções que rompem com o ordenamento (golpes militares, insurreições e protestos populares).

Desse modo, “entre o final do século XIX e o começo do século XX, a tendência foi delegar tal tarefa para um corpo externo ao parlamento" (Ricci e Zulini, 2013, 92). Uma das primeiras alternativas foi a composição combinada (ou eclética) entre políticos e juízes. Para usar os termos da classificação apresentada por Marchetti (2008), era um órgão de controle independente do governo e de formação mista ${ }^{4}$.

A partir da experiência pioneira da Inglaterra, foi adotado o modelo independente do governo, com composição especializada, no qual juízes exercem essa tarefa. Oliveira (2009, 31-32) distingue três variações desenvolvidas ao longo do tempo: 1) aquela em que o controle das eleições é de responsabilidade de membros do judiciário (adotado, por exemplo, na Inglaterra); 2) aquela que confere a um tribunal constitucional a decisão sobre os respectivos meios de impugnação eleitoral, embora combinada com outros meios prévios de caráter também jurisdicional ou, inclusive, de natureza política, que é chamado de modelo austríaco; 3 ) aquela em que essa competência cabe a um ramo especializado em matéria eleitoral pertencente ao Poder Judiciário ou a um órgão judicial autônomo, como é o caso do Brasil e Costa Rica, respectivamente.

Em traços gerais, essa foi a trajetória do Brasil. Da independência até a Revolução de 1930, a “verificação dos poderes" era prerrogativa do legislativo. Na Constituição imperial ela figura nos artigos 21 e 76 (Constituição brasileira de 1824), e na Constituição republicana de 1891 o artigo 18 afirma que "a cada uma das câmaras compete: certificar e reconhecer os poderes de seus membros" (Constituição brasileira de 1891). Conforme Cadah $(2012,34)$, "não havia muito espaço para a atuação do Judiciário em matéria de contestação dos procedimentos de votação e, consequentemente, do resultado. Apenas em casos marginais dos municípios havia alguma possibilidade de demandas pós-eleitorais”.

A realização do pleito, por sua vez, era uma prerrogativa quase exclusiva do governo, que não contava com um órgão específico e

4. A comparação não é perfeita, pois a administração e a execução do pleito continuavam a ser uma prerrogativa do governo, e cabia ao corpo eclético atestar a validade do processo. 
especializado para o desenvolvimento dessa atividade, a qual cabia aos municípios em um processo descentralizado. A participação do judiciário, quando ocorria, ficava circunscrita à organização da lista dos votantes e à presidência das mesas apuradoras, como previsto na Lei Saraiva (1881) e na reforma Bueno de Paiva $(1916)^{5}$. A partir dessa norma,

a presidência da Junta Apuradora não era mais do presidente do governo municipal, mas agora era do juiz federal auxiliado na apuração pelo representante do Ministério Público junto ao Tribunal Superior de Justiça. Como apontado por muitos analistas, esse era o primeiro passo em direção do reconhecimento do poder Judiciário como autoridade incumbida de apurar as eleições (Ricci e Zulini, 2013, 94).

Apesar disso, Sampaio $(1972,127)$ frisa que, como persistia a "verificação dos poderes", a última palavra cabia ao legislativo, "o que anulava o ensaio de jurisdicionalização do processo eleitoral e não deixava de ser uma anomalia, porquanto a apuração levada a efeito pela Justiça ou com sua participação não fazia coisa julgada”.

Larga bibliografia narra as vicissitudes que abrangem todas as etapas dos processos eleitorais realizados durante o Império e a Primeira República ${ }^{6}$. A depender da época, do local e da legislação, neles pululavam episódios de: impropriedade no alistamento dos eleitores (inclusão de pessoas vetadas pela legislação e não inclusão de adversários; duplicidade de inscrição e inserção de falecidos); constrangimento à livre manifestação dos eleitores credenciados (voto a descoberto, a cabresto, assinado, violência, ameaças de agressões físicas, de perda de benefícios ou de emprego, compra de votos); manipulação e fraude na votação (sufrágio de não inscritos,

5. Antes disso, conforme Porto (2000), a legislação de 1824 previa a presença de juiz ordinário na presidência das mesas receptoras de votos, o que foi ampliado em 1842, pois o juiz de paz (de caráter eletivo) passou a presidir a junta responsável pela qualificação dos eleitores e o juiz municipal a decidir litígios referentes à tarefa.

6. Para citar alguns: Carone (1972), Carvalho (2007), Faoro (2001), Fausto (2012), Lessa (1988), Limongi (2012), Porto (2000, 2002, 2004), Ferreira (2005) e, principalmente, Leal (1975). Igualmente, podem ser referenciados contemporâneos a essas situações, como: Souza (1979), ainda nos tempos do Império; e Assis Brasil (1931), no período republicano. 
ausentes, mortos e estrangeiros), bem como na apuração (fabricação de votos e adulteração das atas de escrutínio) ${ }^{7}$. Os problemas prosseguiam no âmbito da "verificação de poderes" e da validação dos eleitos ${ }^{8}$.

A ruptura só ocorreu com o advento da chamada Revolução de 1930, mais especificamente a partir de fevereiro de 1932, com a criação da Justiça Eleitoral, realizada por meio do primeiro Código Eleitoral do país, promulgado como o Decreto n. 21.076 .

O movimento de 30 tinha entre suas bandeiras a moralização das eleições, sumarizada no binômio cunhado por Assis Brasil, 'representação e justiça'. Para isso parecia imprescindível afastar os poderes Executivo e Legislativo da administração e do controle do processo eleitoral, e retirar das Câmaras Legislativas a prerrogativa da verificação dos mandatos (Sadek, 1995, 30).

O novo modelo de governança eleitoral inegavelmente foi adotado no período Vargas e contribuiu decisivamente para a consolidação da "verdade eleitoral”; porém, Silva (2012) argumenta que, mais do que o apreço pela lisura dos pleitos, o que motivava Vargas ao implantar essa e as demais novidades trazidas pelo Código Eleitoral era a busca de vantagens estratégicas na conjuntura de combate às oligarquias, ou seja, elementos políticos circunstanciais. Corrobora tal perspectiva o fato de, poucos anos depois, Vargas ter promovido um golpe de Estado, a partir do qual

7. Ricci e Zulini (2014) afirmam que essas manifestações servem de indício da existência de competição eleitoral, mais do que da falta de pleitos competitivos, como a literatura tem sustentado. Eles demonstram que nas eleições em que a vitória é certa há menos registros de fraudes; ao contrário, surgem mais intensamente naqueles competitivos, pois se tornam "o último recurso para controlar o voto".

8. A bibliografia consagra que essa etapa também estava permeada por fraudes, realizadas por meio da "degola", pelo não reconhecimento dos resultados favoráveis à oposição e pela consequente substituição dos eleitos por apoiadores do governo. Ricci e Zulini (2013) questionam a frequência do não reconhecimento e mostram que elas atingiram $8,7 \%$ do total de diplomas analisados ao longo da Primeira República, e o papel institucional que ele cumpria, pois entendem que dava estabilidade ao sistema e fazia parte da consagração de mecanismos de resolução do contencioso eleitoral. 
extinguiu os partidos, as instâncias parlamentares, as eleições e a própria Justiça Eleitoral.

\section{Fundamentos da Justiça Eleitoral brasileira}

Antes de analisar o modelo de OE instituído pelo Brasil em 1932, é relevante destacar duas características gerais que ele apresenta. A primeira é a opção por uma estrutura institucional dotada de uma série de prerrogativas inusitadas e distintas em comparação às equivalentes internacionais. A segunda é que essa decisão se revelou uma escolha política clara, consciente e que vem sendo continuamente reafirmada, independentemente dos interesses que a impulsionaram ao ser adotada.

Constitucionalizado pela primeira vez em 1934, o OE brasileiro foi mantido praticamente sem mudanças institucionais de fundo em todas as Cartas Magnas que se seguiram, com exceção do texto de 1937. A Justiça Eleitoral é considerada pela classe política um modelo de sucesso e ostenta elevada credibilidade junto à opinião pública. Pesquisa realizada pelo Instituto Nexus em novembro de 2008 , apontou que $73 \%$ dos entrevistados confiavam total ou parcialmente na Justiça Eleitoral, colocando-a em primeiro lugar dentre as instituições relacionadas (Fleischer e Barreto, 2009, 133). Pesquisa realizada pela Fundação Getúlio Vargas em 2013, que cruzou diferentes perguntas para identificar o índice de confiança dos entrevistados em relação à Justiça Eleitoral, chegou a um resultado semelhante: a média foi de 7,2 pontos (Cunha e Oliveira, 2014).

Judicialização do processo eleitoral

O primeiro fundamento diz respeito à opção de fazer do judiciário o responsável pelo $\mathrm{OE}$, atribuindo a tarefa a um ramo especializado e que foi denominado, desde sua criação, Justiça Eleitoral. No atual ordenamento nacional, essa situação está consagrada no artigo $92^{\circ}$, V da Constituição (Brasil, 1988).

Por trás dessa decisão reside a confiança de que o judiciário seja detentor da imparcialidade e da autonomia imprescindíveis para a realização qualificada da governança eleitoral e da consequente 
preservação do interesse público por meio de eleições livres e verdadeiras. Consolidou-se a percepção de que

somente uma estrutura judiciária imparcial, de caráter permanente e com eficiência operativa, acrescida da igualdade do acesso de todos no processo eleitoral e da legitimidade de qualquer dos interessados em promover as medidas em defesa das diversas fases do processo eleitoral poderiam assegurar eleições idôneas (Pinto, 2008, 87).

Assis Brasil, um dos membros da equipe que redigiu o Código Eleitoral de 1932, considerado a fonte das ideias que fundamentaram esse diploma legal, anotou que "o poder Judiciário, pela série de condições que reveste, é em todos os países o mais independente de paixão partidária e o menos subserviente aos governos" (Vale, 2009, 59). Na mesma perspectiva, outro dos redatores do Código Eleitoral de 1932, Rocha Cabral, explicou que a equipe adotou como um dos princípios que "toda matéria de qualificação de eleitores, instrução e decisão de contendas eleitorais será sujeita a jurisdição de juízes e tribunais especiais, com as garantias inerentes ao Poder Judiciário" (Ibidem, 62). Mais recentemente, já com o acúmulo da experimentação da Justiça Eleitoral, mas no mesmo tom apresentado por esses pioneiros, e fazendo eco a uma plêiade de comentadores, Oliveira $(2009,89)$ afirmou:

a experiência de delegar a um ramo especializado do Poder Judiciário o encargo de qualificar as eleições, incluindo o julgamento das controvérsias eleitorais, serve para dotar de confiabilidade o sistema de controle dos pleitos, uma vez que orientado por critérios tipicamente normativos e jurisdicionais, possibilitando que os conflitos sejam dirimidos, com força imperativa, por terceiro, imparcial, sob as garantias constitucionais dirigidas aos litigantes em geral.

Para Andrade Neto (2010,117), seja na Inglaterra quem primeiro fez essa escolha, seja no Brasil, que seguiu tendência que ganhou fôlego no princípio do século XX, a busca não era pela instância judicial em si, e sim por um julgador independente e neutro, o que foi encontrado no judiciário em razão de características típicas da instituição. 
A outra face dessa decisão implicou deliberadamente retirar dos partidos a organização e a execução do processo eleitoral (Marchetti, 2008,880 ), ao mesmo tempo em que exigiu o reconhecimento da impossibilidade de os parlamentares dirimirem com padrões igualitários as controvérsias nas quais eram os principais interessados. De modo semelhante, Guerzoni Filho $(2004,43)$ exalta que a implantação do sistema eleitoral democrático no Brasil decorreu da desconfiança em relação ao sistema político-partidário.

Assim, desde o seu princípio até hoje, o judicializado OE brasileiro tem uma posição institucional "independente", considerando o modo de classificação referenciado anteriormente. Em reforço a essa independência, a Justiça Eleitoral conta com orçamento e com corpo funcional próprio permanente ${ }^{9}$, e os juízes - apesar das peculiaridades a serem comentadas na próxima subseção - gozam das mesmas garantias que os demais membros do judiciário, garantias essas consagradas na Constituição: vitaliciedade, inamovibilidade e irredutibilidade dos vencimentos. Tarouco $(2014,238)$ reputa grande importância a tal característica, pois afirma que as garantias formais da magistratura no Brasil, e o respeito a elas pelos demais poderes, parecem ser o ponto chave para entender a independência da Justiça Eleitoral.

\section{Estrutura e composição}

A segunda característica diz respeito à forma como o modelo de governança eleitoral brasileiro é composto e estruturado. Apesar de formalmente fazer parte do poder judiciário, ele não possui magistratura própria, exclusiva, de carreira, constituída por juízes especializados e concursados para tal ${ }^{10}$. Todos os membros são "emprestados": os juízes eleitorais pertencem à justiça comum ${ }^{11}$

9. Apesar disso, é comum que parte do corpo funcional da Justiça Eleitoral seja composto por funcionários públicos cedidos por órgãos federais, estaduais ou municipais, o que ocorre especialmente na primeira instância.

10. As consequências dessa característica são motivo de discussão entre os especialistas. Apesar de Ribeiro (1996, 130) ser favorável, Russomano (1981, 138), Gomes (2010, 54), Cândido (2010, 46-7) e Lima $(2011,63)$ advogam a carreira própria e especializada, com ingresso mediante concurso público e progressão por critérios de antiguidade.

11. A Constituição Federal de 1988 (art. 121, $\$ 1^{\circ}$ ) e o Código Eleitoral de 1965 (art. 32) dizem que os juízes eleitorais são "de direito", logo estaduais ou de primeira 
e são indicados pelo respectivo Tribunal Regional Eleitoral (TRE); os tribunais regionais são formados por juízes de direito e por membros do Tribunal de Justiça e da Justiça Federal; o tribunal superior, por membros do Supremo Tribunal Federal (STF) e do Superior Tribunal de Justiça (STJ). Por outro lado, como demonstra a relação apresentada acima, apenas membros do judiciário podem ocupar a maior parte dos cargos: as exceções são os advogados, que preenchem aproximadamente um terço das vagas dos TREs e do TSE, e os membros das Juntas Eleitorais, que podem ser pessoas sem formação jurídica obrigatória.

Enquanto atua como membro da Justiça Eleitoral, o juiz não se afasta do cargo e das funções de origem, de modo a acumular as duas atividades ${ }^{12}$. Os membros dos tribunais exercem suas funções por tempo determinado: dois anos, no mínimo, e nunca por mais de dois biênios consecutivos (Brasil, 1988, art. 121, $\left.\$ 2^{\circ}\right)^{13}$. Os juízes eleitorais, em contrapartida, não têm esse horizonte temporal. Como explica Coneglian (2003, 62), "em uma comarca do

instância. Conforme Tavares (2011), essa expressão consta desde a Constituição de 1934, e tem sido usada para distinguir o juiz estadual do federal e para demarcar a intenção de que a primeira instância da Justiça Eleitoral seja, de fato, exercida pela justiça estadual. Entretanto, Almeida Neto $(2014,47)$ relata que, em 2012, diante de um pedido de associações de juízes federais para serem incluídos como membros da Justiça Eleitoral de primeira instância, o TSE precisou reafirmar a interpretação, presente em resolução de 2002, segundo a qual não cabe a eles exercerem o cargo.

12. A medida vale para os advogados que atuam como membros do TSE e dos TREs, que não precisam interromper suas atividades profissionais.

13. Há consenso que essa transitoriedade produz volatilidade na jurisprudência e nos procedimentos adotados pela Justiça Eleitoral; contudo, surgem interpretações divergentes em relação aos significados dessa característica. Sampaio (1972,131) e Ribeiro $(1996,130)$ a consideram positiva, pois o exercício continuado da jurisdição eleitoral gera fricções com os descontentes e, por parte dos juízes, mesmo inconscientemente, pode prejudicar os padrões de neutralidade. Pinto $(2006,37)$ argumenta que, por conta dessa medida, o "Direito Eleitoral está sempre sendo oxigenado [...], respondendo assim às expectativas da sociedade em permanente mutação", com o que concordam Velloso e Agra $(2009,17)$ e Almeida Neto $(2014$, 43). Em sentido oposto, Sadek $(1995,38)$ afirma que a transitoriedade restringe a especialização no Direito Eleitoral, com o que concorda Oliveira (2009), pois, segundo ele, a complexidade do tema exige cada vez mais dedicação e tempo por parte dos magistrados; logo, tal limitação temporal prejudica, ao invés de qualificar, a jurisprudência eleitoral. Na mesma medida, declara que se a transitoriedade dos juízes é garantia de neutralidade das decisões, toda a justiça estaria em xeque, calcada que é em princípio oposto. 
interior, com um único Juiz de Direito, este exercerá a função de Juiz Eleitoral por tempo indeterminado. Enquanto permanecer como Juiz de Direito, será também o Juiz Eleitoral”. Nos casos em que o número de juízes da comarca ultrapassar o de zonas eleitorais, haverá rodízio entre eles para o exercício da função de juiz eleitoral, prevalecendo o mandato de dois anos.

Assim, o modelo de governança brasileiro pode ser classificado como "especializado", pois foi formado a partir de membros vinculados ao meio jurídico (juízes ou advogados), sem que haja a possibilidade de interferência formal dos partidos políticos, do legislativo ou do executivo. No que tange ao método utilizado para a seleção e a indicação dos membros do OE, Marchetti (2008) frisa o fato de sempre ter sido adotada a "regra da interseção" com o judiciário. Essas peculiaridades o distinguem daqueles implantados em outros países latino-americanos ${ }^{14}$.

\section{Concentração em um único órgão}

O modelo de OE adotado pelo Brasil concentra em uma única instituição as atividades administrativas (rule application) e as de julgamento e de solução do contencioso eleitoral (rule adjudication).

Apesar de a denominação "Justiça Eleitoral” indicar a ênfase ao caráter judicial, o que é reforçado pelo fato de ser declarada constitucionalmente como parte do poder judiciário, ela não atua apenas como órgão jurídico, "consistente em dizer o direito aplicável à espécie nos casos que lhe são submetidos, desde que alusivos ao processo eleitoral" (Pinto, 2008, 93). O OE brasileiro também desempenha as tarefas necessárias para a realização das eleições, o que significa que além de ter retirado do legislativo a prerrogativa de "verificar poderes" igualmente o fez no que tange a do executivo em promover a disputa eleitoral. Assim, ele a prepara, organiza e executa, o que pode ser discriminado na realização de três grandes atividades: (1) credenciar os eleitores

14. Quem mais se aproxima do modelo brasileiro é a Costa Rica, no qual partidos, executivo e legislativo não participam do $\mathrm{OE}$, formado a partir de indicação judicial. No entanto, a "regra da interseção" é vedada, pois os membros da Corte Suprema que indicam os membros não podem compor o OE. 
e os competidores; (2) cuidar da coleta dos votos; (3) promover a apuração dos votos e a divulgação os resultados.

Autores frisam que essa é a principal atividade da Justiça Eleitoral ou, pelo menos, aquela a que ela mais se dedica e que mais a caracteriza. O ministro do TSE Sepúlveda Pertence (apud Almeida Neto, 2014, 54), afirmou, em 1992, que a direção do processo eleitoral era a finalidade primeira da Justiça Eleitoral. Jardim (1998, 40) anota: "embora montada em modelo tipicamente judiciário - estrutura, forma, pessoal, vestes talares e jargão judiciário, sua tarefa é essencialmente administrativa, e só eventualmente jurisdicional". De modo convergente, Coneglian (2003, 58) afirma: "enquanto todas as atividades fins de todos os órgãos da Justiça é julgar, ou exercer a jurisdição, a atividade fim da Justiça Eleitoral é realizar as eleições. Daí que a Justiça Eleitoral é o Poder Executivo das eleições”.

E como “órgão executivo" do processo eleitoral, ela tem algumas peculiaridades em comparação a outras instituições judiciais:

nos seus atos de administração, pode e deve agir de ofício, independentemente de provocação, notadamente para garantir a lisura do processo eleitoral, a liberdade no exercício do voto e o equilíbrio na disputa eleitoral. Apenas quando no exercício de sua função jurisdicional pura, a Justiça Eleitoral deve manter-se estática (Pinto, 2008, 96).

Ressalva-se que tal poder de polícia - consubstanciado no Código Eleitoral por meio do art. 35, XVI, segundo o qual compete ao juiz eleitoral "tomar todas as providências ao seu alcance para evitar os atos viciosos nas eleições" - é relevante para que a Justiça Eleitoral possa zelar pelo modo como a propaganda eleitoral é desenvolvida e para que coíba os excessos e erros cometidos nesse campo, os quais afetam o processo de formação das preferências do eleitor e, portanto, influem diretamente na lisura e na qualidade do pleito, cuja garantia é o objetivo maior do OE brasileiro ${ }^{15}$.

15. Há consenso em torno dos êxitos atingidos pela governança eleitoral brasileira no que tange à correta, verdadeira e rápida expressão, captação e contagem dos votos, consolidados especialmente após a adoção da urna eletrônica. Porém, continuam como desafios: garantir a autonomia da formulação da decisão do eleitor e coibir 
Para o cumprimento das atividades vistas nos parágrafos precedentes, a Justiça Eleitoral possui duas funções: 1) jurisdicional, que é típica de todo e qualquer órgão judicial, ou seja, a de decidir as contendas, somente quando e se provocada ${ }^{16}$; e 2) administrativa $^{17}$. Ambas já estão no Código Eleitoral de 1932, cujo artigo $5^{\circ}$ afirma: "é instituída a Justiça Eleitoral, com funções contenciosas e administrativas".

No texto constitucional vigente, entretanto, não figura a mesma clareza e precisão quanto a essas funções.

A única menção direta às funções não jurisdicionais da Justiça Eleitoral avistável no corpo da Constituição está no art. 17, ao tratar do registro de partidos políticos e da obrigação de prestação de contas das agremiações. Uma busca mais aprofundada no texto constitucional, entretanto, demonstrará que as atribuições não jurisdicionais da Justiça Eleitoral são pressupostas pela Constituição, com base na herança do direito pré-constitucional. Assim, é no Ato das Disposições Constitucionais Transitórias que se encontram as regras que indiretamente atribuem à Justiça Eleitoral as funções não

de modo eficaz práticas que promovem a fraude e a inautenticidade eleitorais sem que seja necessário violar os procedimentos de votação, as urnas ou a apuração, nos casos de: uso da máquina pública; a forma como os recursos de campanha são arrecadados e utilizados. Essa era a crítica de Leal $(1975,234)$ à Justiça Eleitoral, formulada já nos anos 1940: "o código de 1932, aperfeiçoado pela reforma de 35 , apesar dos louvores que mereceu, não punha fim à costumeira coação dos partidos oficiais. Não nos referimos à coação direta e material no dia do pleito ou no ato de votar. Nem era esta a mais frequente modalidade de compressão do voto na vigência das leis anteriores. Aludimos à coação difusa, mas efetiva, que em muitos lugares precede as eleições no interior do país; ao ambiente de insegurança adrede criado para os eleitores da oposição, que nos menores municípios toda gente conhece; à violência preparatória, atual ou iminente manifestada com pertinácia em pequenas ou grandes façanhas, dias, semanas e até meses a fio". Para mais informações sobre os impasses, os esforços e as dificuldades legais, administrativas e orçamentárias da Justiça Eleitoral para combater essas formas difusas de fraudes, ver: Bohn et al. (2002); Taylor (2006); Oliveira (2009).

16. Apesar disso, ela possui prazos mais exíguos que os demais ramos do judiciário, já que a demora na tomada de decisões significa sua não concretização, tendo em vista que a data das eleições não pode ser postergada, como argumentam Velloso e Agra $(2009,16)$.

17. Elas não se referem ao aspecto interno, comum a todos os organismos legislativos e judiciários, mas sim à execução do próprio processo eleitoral. 
jurisdicionais que conhecemos. Em resumo, não temos um dispositivo constitucional que cometa diretamente à Justiça Eleitoral as atribuições de administração e regulamentação das eleições (Pelella, 2012, 137-8).

No atual ordenamento jurídico nacional, o caput do artigo 121 reserva à lei complementar "a organização e competência dos tribunais, dos juízes de direito e das juntas eleitorais”. No entanto, essa lei complementar não foi realizada até o momento, de modo que o Código Eleitoral de 1965 (Lei 4.737), apesar de ser originalmente uma lei ordinária, foi recepcionado como tal e é quem regulamenta o art. 121 em todos aqueles pontos em que não colide com a Carta de 1988. A ele podem ser acrescentadas outras normas infraconstitucionais produzidas ao longo do tempo, como: lei orgânica dos partidos políticos (Lei 9.096/95), lei geral das eleições (Lei 9.504/97), lei complementar das inelegibilidades (LC 64/90).

\section{Função normativa}

Em decorrência de suas atribuições administrativas, a Justiça Eleitoral possui uma terceira função, que é normatizar o pleito e consequentemente exercer o poder normativo. Como nos casos anteriores, tal prerrogativa consta desde a sua criação, pois o primeiro Código Eleitoral determina que a ela cabe fixar normas uniformes para aplicação das leis e regulamentos eleitorais, expedindo instruções que entenda necessárias (Brasil, art. 14, 5). No atual ordenamento jurídico, o Código Eleitoral de 1965 (art. 1º, parag. único; art. 23, IX), a lei orgânica dos Partidos Políticos (art. 61) e a lei geral das eleições (art. 105) trouxeram a previsão da expedição das instruções necessárias a sua fiel execução ${ }^{18}$.

O poder normativo da Justiça Eleitoral é entendido como "a prerrogativa de interpretar o ordenamento jurídico-eleitoral, de estabelecer o alcance e o de definir o sentido da vontade normativa

18. Também incluíam tal prerrogativa as leis emitidas antes do advento da chamada "lei das eleições" e que disciplinavam cada processo eleitoral em particular. Almeida Neto $(2013,254)$ ainda arrola o art. 27 da lei 6.091/74, que dispõe a respeito do fornecimento de transporte aos eleitores da zona rural em dia de votação, e o art. 18 da lei 6.996/82, que dispõe acerca da utilização eletrônica de dados. 
proclamada pelo Estado em matéria eleitoral" (Pinto, 2008, 114). Contudo, o entendimento jurisprudencial do TSE é de que "essa competência não atinge apenas o poder de regulamentar a lei, mais a de "emprestar-lhe o sentido que a compatibilize no qual se insere" (Lima, 2011, 79).

Desse modo, ele abrange dois tipos de decisões: a) atos normativos secundários, assim concebidos como aqueles de hierarquia infralegal que complementam uma norma legal e asseguram a sua fiel execução (Pinto, 2008, 114-6); b) atos normativos primários, aqueles de cunho supletivo e criador, desde que sua aplicação não seja incompatível com a lei regulamentada (Pinto, 2008, 118). Na síntese de Almeida Neto $(2014,173)$, “devem ser expedidas segundo a lei (secundum legem) ou para suprimir alguma lacuna normativa (praeter legem), jamais devem contrariar uma lei (contra legem) ou mesmo inovar em matéria legislativa".

Para Lima (2011, 94-5), entretanto, esses atos criadores podem ir além de "preencher o vazio" legal e adquirir novas dimensões, discriminados em três aspectos: a) o conteúdo não está previsto nas normas legais que atribuem à Justiça Eleitoral tal poder; b) a matéria já foi objeto de lei, mas o sentido atribuído inclui novas previsões; c) o conteúdo é incompatível com a lei.

Por essa via, verifica-se que, além de realizar o rule application e o rule adjudication, a Justiça Eleitoral tem a possibilidade de exercer - e vem efetivando tal possibilidade - o rule making, junto, ao lado, e às vezes em substituição ao legislativo. Conforme Taylor $(2006,148)$,

apesar de ser uma instituição da Justiça, a Justiça Eleitoral não somente adjudica disputas no âmbito eleitoral, mas também reúne atribuições dos poderes Executivo e Legislativo: administra e gerencia as eleições e estabelece regras legais através da emissão de instruções normativas.

Tal poder normativo é prerrogativa privativa do TSE, pois os juízes eleitorais e os tribunais regionais não podem exercê-lo ${ }^{19}$. A concentração no órgão de cúpula garante que as mesmas regras tenham validade uniformemente em todo território nacional, o que

19. Apesar disso, os TREs podem responder a consultas, que se tornam resoluções e podem implicar algum tipo de normatização. 
é coerente à determinação constitucional da competência privativa da União para legislar em direito eleitoral (Brasil. CF 1988, art. 22, I), e contrasta com a descentralização no gerenciamento das normas que caracteriza o OE brasileiro, afinal, o TSE só tem responsabilidade direta pela realização da eleição presidencial.

\section{Função consultiva}

Há outra prerrogativa da Justiça Eleitoral, igualmente inusitada em relação a outros órgãos do poder judiciário: a de responder a consultas, ou seja, sanar uma dúvida sobre a interpretação da lei e o modo como ela deve ser aplicada. As consultas são definidas como um "tipo de processo em que o Tribunal Superior Eleitoral e os tribunais regionais eleitorais respondem a questionamentos formulados em tese por pessoas legitimadas sobre matéria eleitoral" (TSE. Consulta. Glossário Eleitoral).

Hoje, tal competência está regulamentada no Código Eleitoral: no que tange ao TSE no art. 23, XII e no que se refere aos tribunais regionais no art. 30, VIII (Brasil. Código Eleitoral). As pessoas legitimadas a formularem a consulta são, conforme o caso: autoridades com jurisdição federal e estadual; órgãos de direção partidária de abrangência nacional, estadual ou municipal, bem como os TREs em relação ao TSE.

Vários autores procuram justificar a existência dessa função. Para Jardim $(1998,183)$ ela decorre de: "a celeridade do processo eleitoral, a necessidade de reduzirem-se os conflitos e os litígios e a conveniência de previsibilidade legal". Na opinião de Gomes (1998, 173), ela é pedagógica e resulta que todos os partícipes do processo eleitoral possam cumprir com maior certeza os postulados legais. Conforme Machado (2013, 282), “as consultas muitas vezes funcionam como esclarecimentos prévios sobre as regras do jogo, o que contribui para a preservação da legitimidade e da estabilidade do sistema político-eleitoral". Em uma linha mais crítica, mas convergente com os anteriores, Silva $(1998,35)$ relata que

um feixe de fatos de natureza sociológica, política e jurídica determinaram historicamente esta competência. O primeiro deles é a absoluta assistematização do que se pode chamar de Direito Eleitoral. Em torno do Código, editado em 1965, orbitam inúmeras disposições 
legais de caráter substantivo e adjetivo, numa sobreposta e contínua auto-revogação da lógica interna do sistema. Tal acontece pela costumeira urgência com que se delibera e se vota a legislação eleitoral. [...] O emaranhado legislativo formado, juntamente com as resoluções complementares da própria Justiça Eleitoral, tornou este campo do direito um verdadeiro pântano jurídico, inacessível de ser penetrado com segurança mesmo aos já iniciados. A possibilidade de - através do procedimento de consulta - requerer, junto a um órgão jurisdicional, pura interpretação de norma jurídica consiste em verdadeira confissão pública de que, efetivamente, há muito tempo, a lei não oferece certeza ou segurança jurídica.

Diferentemente das ações judiciais (com exceção das ações diretas de inconstitucionalidade e das ações declaratórias de constitucionalidade), as consultas dispensam a existência e a identificação das partes de um litígio, ou seja, como diz a definição apresentada anteriormente, devem ser formuladas em tese, sem a existência de um caso concreto em debate. Dadas essas características, persiste a polêmica em torno da validade da resposta às consultas e do caráter que ela assume. Uma corrente afirma que

não envolve, propriamente, decisão, mas a exteriorização do entendimento, em tese, dos Tribunais, sobre matéria eleitoral, provocada pelo interessado. Tal resposta não envolve julgamento de lide eleitoral, mas simples esclarecimento de dúvida suscitada pelo consulente, extraprocesso, por meio de mera indagação subscrita, embora processualmente autuada. Não se trata de decisão sobre um direito contestado, mas de mera resposta, expressando a opinião do Tribunal consultado, e que, naturalmente, não exclui reconsideração. Por conseguinte, a resposta da consulta não constitui coisa julgada, permitindo, ao contrário, renovação do questionamento (Pinto, 2008, 133).

Nesse sentido, elas não têm caráter normativo ou jurisdicional e podem

servir de orientação ao juiz na decisão de um caso concreto que venha a ocorrer no futuro, mas não há obrigatoriedade de vinculação da resposta dada em consulta com a decisão judicial. Em outras palavras, 
quando diante do caso concreto, a decisão pode ser diferente daquela indicada pela resposta à consulta (Marchetti, 2008, 889).

O entendimento do STF, firmado em 1998, confirma que as consultas não possuem caráter vinculativo ou obrigatório (Almeida Neto, 2010, 94).

Para outra corrente, entretanto, a resposta a essas consultas costuma servir de balizamento às decisões a serem tomadas pelo tribunal que a proferiu e às instâncias inferiores da Justiça Eleitoral, bem como aos próprios formuladores da consulta. Noleto $(2008,17)$ argumenta que a não especialização dos juízes eleitorais acaba por torná-los mais dependentes das orientações das instâncias superiores. Logo, na prática, assumem caráter vinculativo ou obrigatório até porque, como opina Rosas (1992, 21), “a letra do Código Eleitoral não é uma vana verba, sem expressão. Hoje um pronunciamento da Corte, amanhã diferente. Não teria sentido a resposta afirmativa à consulta posteriormente alterada pelo próprio Tribunal, quando se apresentam as questões de forma idêntica”.

Por tudo isso, na visão de Vale $(2009,93)$,

a Justiça Eleitoral não se configurou como 'a boca inanimada da lei' de Montesquieu. Ao contrário, sempre muito ativa e propositiva, a Justiça Eleitoral é uma justiça especial com poderes de controle sobre os demais poderes, pelo menos no que diz respeito a quem exercerá os cargos nos demais poderes.

Lima $(2011,84)$ aponta que

a criação de regra não prevista em lei através de resolução normativa, no que se incluem as respostas a consultas, vêm se produzindo de modo independente da aprovação do Congresso Nacional e revelando, cada vez mais, a autonomia do TSE no trato de assuntos eleitorais.

\section{Conclusão}

O artigo realizou uma revisão da literatura dos campos da Ciência Política e do Direito Eleitoral, a partir da qual procurou 
inserir as análises em torno das características da Justiça Eleitoral brasileira no modelo teórico-interpretativo da governança eleitoral, que vem ganhando espaço em âmbito internacional ao fornecer parâmetros para interpretar o modo como as eleições são constituídas, administradas e os conflitos julgados e solucionados, com vistas à promoção de disputas livres e limpas, cujos resultados são reconhecidos e respeitados pelos competidores e opinião pública.

A análise mostrou que a Justiça Eleitoral pode ser explicada e analisada por meio da noção de governança eleitoral; porém, igualmente, que o arranjo institucional brasileiro estabelecido desde a sua criação em 1932, e a série de prerrogativas associadas a ela, tornam-na um modelo peculiar de governança eleitoral em comparação aos padrões internacionais. Essa escolha foi produto de uma escolha política consciente e que vem dando bons resultados, razão pela qual desde então o organismo eleitoral brasileiro não sofreu mudanças de fundo.

A primeira delas é a de judicializar o processo eleitoral por considerar que a instituição judiciária tem mais capacidade e neutralidade para exercer tal tarefa, garantindo assim eleições livres e limpas. A segunda é que, além de "independente" (formado sem participação do governo e dos partidos), o OE brasileiro é também “especializado”, pois é composto unicamente por membros vinculados ao meio jurídico (juízes, especialmente os do STF, e advogados). A terceira é que todas as atividades atinentes ao pleito - da qualificação dos eleitores à diplomação dos eleitos - estão concentradas em uma única instituição, que exerce, por isso, as atividades administrativas (rule application) e as de solução do contencioso eleitoral (rule adjudication). Por fim, a Justiça Eleitoral brasileira também tem a prerrogativa de produzir resoluções que esclarecem e dão sentido às leis relativas ao pleito e/ou responder consultas sobre interpretações hipotéticas relativas ao entendimento ou à extensão das normas, de forma a exercer, também, o rule making, junto, a lado, e às vezes em substituição ao legislativo.

Assim, esse OE judicializado, independente e especializado abrange e tem participação nas três dimensões que compõem a governança eleitoral, de modo a garantir a qualidade de cada uma e a interação 
entre elas, bem como do conjunto do processo eleitoral, fortalecendo assim as instituições democráticas.

\section{Referências}

ALMEIDA NETO, M. C. de. (2010). Reflexões sobre a nova tipologia das resoluções do Tribunal Superior Eleitoral. Estudos Eleitorais, vol. 5, n. 2, p. 92-105. - (2013). A Função administrativa da Justiça Eleitoral brasileira. In: CAGGIANO, M. H. S. (coord.). Direito Eleitoral em debate - estudos em homenagem a Cláudio Lembo. São Paulo: Saraiva. . (2014). Direito Eleitoral regulador. São Paulo: Revista dos Tribunais.

ANDRADE NETO, J. (2010). Jurisdição eleitoral: judicialização da política? Revista Jurídica da Presidência, vol. 12, n. 96, p. 106-130.

ASSIS BRASIL, J. F. (1931). Democracia representativa: do voto e do modo de votar. 4. ed. rev. aum. Rio de Janeiro: Imprensa Nacional.

BOBBIO, N. (1997). O futuro da democracia. 6. ed. Rio de Janeiro: Paz e Terra.

BOHN, S. R. da S. et al. (2002). A fiscalização das eleições. In: SPECK, B. (org.). Caminhos da transparência. Campinas: Unicamp.

BRASIL. Constituição de 1824. Disponível em: [http://www.planalto.gov.br/ccivil_03/constituicao/constituicao24.htm]. Acesso em 24 de julho de 2014.

. Constituição de 1891. Disponível em: [http://www.planalto.gov.br/ccivil_03/ constituicao/constituicao91.htm]. Acesso em 24 de julho de 2014.

. Código Eleitoral de 1932. Disponível em: [http://legis.senado.gov.br/legislacao/ListaPublicacoes.action?id=33626]. Acesso em 24 de julho de 2014.

. Código Eleitoral. Lei n. 4.737, de 15 de julho de 1965. Disponível em: [http:// www.planalto.gov.br/ccivil_03/leis/14737.htm]. Acesso em 24 de julho de 2014.

. Constituição da República Federativa do Brasil de 1988. Disponível em: [http://www.planalto.gov.br/ccivil_03/constituicao/constituicao.htm]. Acesso em 24 de julho de 2014.

CADAH, L. Q. (2012). Instituições eleitorais e competição política - a criação da Justiça Eleitoral no Brasil.2012, 81f. Dissertação (Mestrado em Ciência Política). Universidade de São Paulo, São Paulo.

CÂNDIDO, J. (2010). Direito Eleitoral brasileiro. 14. ed. rev. atual. Bauru: Edipro.

CARONE, E. (1972). A República Velha. São Paulo: Difel.

CARVALHO, J. M. de. (2007). Cidadania no Brasil: o longo caminho. 9. ed. São Paulo: Civilização Brasileira.

CONEGLIAN, O. (2003). A Justiça Eleitoral: o Poder Executivo das eleições, uma justiça diferente. In: TEIXEIRA, S. de F. (coord.). Direito eleitoral contemporâneo: doutrina e jurisprudência. Belo Horizonte: Del Rey. 
CUNHA, L. G.; OLIVEIRA, F. L. (2014). Justiça Eleitoral: opinião pública e confiança institucional. Cadernos Adenauer, vol. 15, n. 1, p. 191-210.

DAHL, R. (2001). Sobre a democracia. Brasília: UnB.

FAORO, R. (2001). Os donos do poder. 3. ed. Rio de Janeiro: Globo.

FAUSTO, B. (2012). História do Brasil. 12. ed. São Paulo: Edusp.

FERREIRA, M. R. (2005). A evolução do sistema eleitoral brasileiro. 2. ed. rev. aum. Brasília: TSE.

FLEISCHER, D.; BARRETO, L. (2009). El impacto de la Justicia Electoral sobre el sistema político brasileño. América Latina Hoy, vol. 51, p. 117-138.

GOMES, J. J. (2010). Direito Eleitoral. 4. ed. Belo Horizonte: Del Rey.

GOMES, S. de C. (1998). A Justiça Eleitoral e sua competência. São Paulo: Revista dos Tribunais.

GUERZONI FILHO, G. (2004). A Justiça Eleitoral no Brasil - a desconfiança como elemento fundamental de nosso sistema eleitoral. Revista de Informação Legislativa, vol. 41, n. 161, p. 39-45.

HARTLYN, J. et al. (2009). La importancia de la gobernanza electoral y la calidad de las elecciones en la América Latina contemporánea. América Latina Hoy, vol. 51, p. 15-40.

HENRÍQUEZ, J. O. (2007). El contencioso electoral, la calificación electoral. In: NOHLEN, D. et al. (comp.). Tratado de Derecho Electoral comparado de América Latina. 2. ed. México: Fondo de Cultura Económica; Instituto Interamericano de Derechos Humanos, Universidad de Heidelberg, International IDEA, Tribunal Electoral del Poder Judicial de la Federación, Instituto Federal Electoral.

JARDIM, T. (1998). Direito Eleitoral positivo. 2. ed. rev. aum. Brasília: Brasília Jurídica.

LEAL, V. N. (1975). Coronelismo, enxada e voto. 2. ed. Rio de Janeiro: Alfa-ômega.

LEHOUCQ, F. (2002). Can parties police themselves? Electoral governance and democratization. International Political Science Review, vol. 23, n. 1, p. 29-46.

LESSA, R. (1988). A invenção republicana. Rio de Janeiro: Vértice.

LIMA, S. M. P. O Ativismo judicial e o judiciário eleitoral: um estudo da atividade legislativa do Tribunal Superior Eleitoral. 2011, 198f. Tese (Doutorado em Ciência Política). Universidade Federal de Pernambuco, Recife.

LIMONGI, F. (2012). Eleições e democracia no Brasil: Victor Nunes Leal e a transição de 1945. Dados, vol. 55, n. 1, p. 37-69.

MACHADO, M. P. (2013). A Justiça Eleitoral. In: CAGGIANO, M. H. S. (coord.). Direito Eleitoral em debate - estudos em homenagem a Cláudio Lembo. São Paulo: Saraiva.

MARCHETTI, V. (2008). Governança eleitoral: o modelo brasileiro de Justiça Eleitoral. Dados, vol. 51, n. 4, p. 865-893. 
MOLINA, J.; HERNÁNDEZ, J. (1998). La credibilidad de las elecciones latinoamericanas y sus factores. El efecto de los organismos electorales, el sistema de partidos y las actitudes políticas. In: XXI Congreso Internacional LASA, Chicago.

MOZAFFAR, S.; SCHEDLER, A. (2002). The comparative study of electoral governance - introduction. International Political Science Review, vol. 23, n. 1, p. 5-27.

NOLETO, M. A. (2008). Terceiro turno - crônicas da jurisdição eleitoral. 2. ed. rev. aum. Imperatriz: Ética.

OLIVEIRA, M. R. O Sistema Jurisdicional de controle das eleições: virtudes e vícios do modelo constitucional brasileiro de apuração da verdade eleitoral. 2009, $118 \mathrm{f}$. Dissertação (Mestrado em Direito Constitucional). Universidade de Fortaleza, Fortaleza.

PELLELA, E. (2012). A Justiça Eleitoral e o Ministério Público Eleitoral - considerações sobre o sistema de administração, regulação, normatização e controle das eleições no Brasil. In: RAMOS, A. de C. (org.). Temas de Direito Eleitoral no século XXI. Brasília: Escola Superior do Ministério Público da União.

PINTO, D. (2006). Direito eleitoral: improbidade administrativa e responsabilidade fiscal - noções gerais. 3. ed. rev. atual. São Paulo: Atlas.

PINTO, E. R. G. de C. O Poder normativo da Justiça Eleitoral. 2008, 191f. Dissertação (Mestrado em Direito). Universidade Federal do Ceará, Fortaleza.

PORTO, W. C. (2000). Dicionário do voto. Brasília: UnB. . (2002). O voto no Brasil. 2. ed. Rio de Janeiro: Topbooks. . (2004). A mentirosa urna. São Paulo: Martins Fontes.

PRZEWORSKI, A. (1984). Amas a incerteza e serás democrático. Novos Estudos, n. 9, p. 36-46.

RIBEIRO, F. (1996). Direito Eleitoral. 4. ed. Rio de Janeiro: Forense.

RICCI, P.; ZULINI, J. P. (2013). Quem ganhou as eleições? A validação dos resultados eleitorais antes da criação da justiça eleitoral. Revista de Sociologia e Política, vol. 21, n. 45, p. 91-105.

. (2014). Partidos, competição política e fraude eleitoral: a tônica das eleições na Primeira República. Dados, vol. 57, n. 2, p. 443-479.

ROSAS, R. (1992). Estrutura constitucional da Justiça Eleitoral. Arquivos do Ministério da Justiça, vol. 45, n. 179, p. 5-21.

RUSSOMANO, R. (1981). Sistemas eleitorais. Justiça Eleitoral - sua problemática no constitucionalismo brasileiro. Revista de Informação Legislativa, vol. 18, n. 71, p. 133-140.

SADEK, M. T. A. (1995). A Justiça Eleitoral e a consolidação da democracia no Brasil. São Paulo: Konrad Adenauer.

SAMPAIO, N. de S. (1972). A Justiça Eleitoral. Revista Brasileira de Estudos Políticos, n. 34, p. 111-153. 
SARTORI, G. (1982). Partidos e sistemas partidários. Brasília: UnB.

SCHUMPETER, J. (1984). Capitalismo, socialismo e democracia. Rio de Janeiro: Zahar.

SILVA, E. A. da. As transformações no quadro partidário brasileiro pós-Revolução de 1930. 2012, 126f. Dissertação (Mestrado em Ciência Política). Universidade de São Paulo, São Paulo.

SILVA, E. S. da. (1998). Jurisdição e Positivismo Jurídico: breves reflexões sobre o procedimento de consulta na Justiça Eleitoral. Revista do TRE/RS, vol. 3, n. 7, p. 30-45.

SOUZA, F. B. de. (1979). O sistema eleitoral no Império. Brasília: Senado Federal.

TAROUCO, G. da S. (2014). Governança eleitoral: modelos institucionais e legitimação. Cadernos Adenauer, vol. 15, n. 1, p. 229-243.

TAVARES, A. R. (2011). Justiça e administração eleitorais na federação brasileira: entre a justiça estadual e federal. Estudos Eleitorais, vol. 6, n. 2, p. 9-28.

TAYLOR, M. (2006). Justiça Eleitoral. In: AVRITZER, L.; ANASTASIA, F. (org.). Reforma politica no Brasil. Belo Horizonte: UFMG.

TRIBUNAL SUPERIOR ELEITORAL. Consulta. Glossário Eleitoral. Disponível em: [http://www.tse.jus.br/eleitor/glossario/termos-iniciados-com-a-letra-c\#consulta]. Acesso em 22 de julho de 2014.

VALE, T. C. de S. C. Justiça Eleitoral e judicialização da política: um estudo através da história. 2009, 233f. Tese (Doutorado em Ciência Política). Instituto Universitário de Pesquisa do Rio de Janeiro, Rio de Janeiro.

VELlOSO, C. M. da S.; AGRA, W. de M. (2009). Elementos de Direito Eleitoral. São Paulo: Saraiva. 